\title{
Private post-secondary library websites and the ADA: compliancy and COVID-19
}

\author{
Arlene Bielefield $^{1} \cdot$ Yan Quan Liu ${ }^{1}$ (D) $\cdot$ Victoria Waimon $^{1}$ \\ Accepted: 18 July 2021 / Published online: 21 August 2021 \\ (c) The Author(s), under exclusive licence to Springer-Verlag GmbH Germany, part of Springer Nature 2021
}

\begin{abstract}
This study explores whether US post-secondary institutions (PPI) follow philosophies to foster inclusive communities, providing resources for those individuals with disabilities thrive socially, personally, and academically, while there have been no thorough studies conducted to determine web accessibility of the nation's top-ranked PPI library webpages. Additionally, this study pioneers in comparison with the accessibility of PPI's library homepages fighting COVID-19. The study evaluated the library homepages of the premium PPIs based on Money.com's 2019 list of "The Best Colleges in America" via the WAVE web accessibility evaluation tool. The outcomes determined that most of the library homepages analyzed were littered with numerous errors, and the shift to online-based research in learning had no significant impact on the number of errors WAVE detected. The disconcerting findings of this study demonstrate the overall failure to recognize the importance of web accessibility or perhaps even the indifference toward accessibility on the part of the PPI community.
\end{abstract}

Keywords Accessibility $\cdot$ Disability $\cdot$ ADA $\cdot$ Section $508 \cdot$ Academic libraries $\cdot$ COVID-19 $\cdot$ Private colleges and universities $\cdot$ WAVE $\cdot$ WCAG

\section{Introduction}

Committed. Accommodating. Equality. One or more of these words is often found on the websites of the top private postsecondary institutions (PPI) in the USA. The University of Richmond (n.d.) boasts it is "committed to making its website properties accessible to the widest possible audience" [29]. Similarly, California Technical Institute (Caltech) (n.d.) claims "CASS (Caltech Accessibility Services for Students) will make every reasonable effort to provide academic adjustments and other reasonable accommodations to otherwise qualified students with known disabilities" [12]. Continual maintenance and ongoing academic and technical support are imperative to sustain a genuine universally accommodating institution. Although the majority of PPIs shine inclusivity in mission statements, there is a greater reason for the push for accommodation and accessibility: the law.

As stated in the US Census Bureau report, $27.2 \%$ of the 2014 US adults aged 18 lived with a disability (Taylor, 2).

Yan Quan Liu

liuy@ southernct.edu

1 Information and Library Science, Southern Connecticut State University, New Haven, CT, USA
Further, the National Center for Education Statistics (NCES) [15] reported that $19.4 \%$ of students enrolled in an undergraduate program in 2015-2016 had a disability ("Fast facts: Students with disabilities"). A significant number of undergraduate students in the USA live and learn with a disability. Therefore, accommodations for these individuals must be made available in all educational sectors of life.

The Americans with Disabilities Act of 1990 (ADA) was created and amended throughout the years to ensure "equal opportunity for persons with disabilities in employment, state and local government services, public accommodations, commercial facilities, and transportation" [2, para. 1]. Part 36 Nondiscrimination on the Basis of Disability in Public Accommodations and Commercial Facilities (2010) states:

The purpose of this part is to implement title III of the Americans with Disabilities Act of 1990 (42 U.S.C. 12181), which prohibits discrimination on the basis of disability by public accommodations and requires places of public accommodation and commercial facilities to be designed, constructed, and altered in compliance with the accessibility standards established by this part. 
Currently, under Title II of the ADA, all privately funded schools are mandated to adhere to the ADA guidelines.

Further, Section 504 of the Rehabilitation Act prohibits an individual with a disability to "be excluded from the participation in, be denied the benefits of, or be subjected to discrimination under program or activity receiving Federal financial assistance" (U.S. Department of Labor, Section 504, Rehabilitation Act of 1973). Because the majority of PPIs receive federal funding in the form of research and tuition grants, they must adhere to the laws of the Rehabilitation Act.

In response to the prevalence of online learning, databases, and overall increased use of the Web, the World Wide Web Consortium (W3C), an international organization dedicated to creating standards and practices for the accessibility on the World Wide Web, founded the Web Accessibility Initiative (WAI) to further set universal standards pertinent to web accessibility. In 1996, the WAI was formed and produced the Web Content Accessibility Guidelines (WCAG 1.0) in 1999. WCAG (1.0) is comprised of 14 broad guidelines for web accessibility and multiple checkpoints which aid in effectively applying said guidelines to specific portions of web pages.

Since its inception, WCAG 1.0 has been amended and adapted to combat the everchanging technological landscape. According to the W3C [26], WCAG 1.0 has been improved and modified multiple times since 1999: WCAG 2.0 [28], WCAG 2.1 [30], and WCAG 2.2 (scheduled to be published in 2021) ("Web Content Accessibility Guidelines [WCAG] overview"). WCAG 2.0 and WCAG 2.1 are both current standards meant to be used synchronously.

In contrast to WCAG 1.0, WCAG 2.0 applies to broader scope of technologies and allows for compatibility with future technologies. WCAG 2.0 features four principles of web accessibility: perceivability, operability, understandability, and robustness. This success criteria further entail a set of various guidelines and each guideline's importance, valued at Levels A, AA, or AAA. In 2018, WCAG 2.1 was implemented as an addendum to WCAG 2.0 to create an even more comprehensive set of success criteria. According to the W3C (2020), WCAG 2.1 contains 17 additional success criteria to strengthen WCAG 2.0 by addressing mobile accessibility, people with low vision, and people with cognitive and learning disabilities ("What's new in WCAG 2.1").

Most top-ranked PPIs have generally adhered to the laws concerning accessibility. Out of 100 institutions researched, 68 have an easily accessible and informative online resource designated for persons with disabilities in their respective communities. Additionally, all 68 of these schools explicitly refer to the Rehabilitation Act, the ADA, and/or WCAG as driving forces behind their accessibility guidelines.
It is now important, more than ever before, to provide barrier-free online accommodations for the communities of PPI. In the wake of COVID-19, there has been a prominent shift to online learning and research. Many US College and university libraries have temporarily closed their doors or are offering limited access amid this international pandemic. A number of PPI libraries that chose to remain open now adhere to a strict set of policies including no inperson reference services, no access to the library stacks, and required reservations for use of study areas.

The desire for accessibility should not only be applied to an institution's physical infrastructure but also to all technological aspects of the school, more specifically, the library website. One of the core tenets of librarianship is to ensure that "all library resources and programs are accessible to all overcoming technological and monetary barriers to access" [18, p. 27]. To this end, all PPIs should champion for providing an ADA compliant, universally accessible website.

\section{Research focus}

Upon conducting the literature review, it is apparent that information regarding the top-ranked US PPIs and the level of web accessibility of their library websites is lacking considerably. The challenge of COVID-19 has forced institutions to rethink the way in which knowledge is disseminated. This study will reveal what measures have been taken, if any, by the top-ranked PPI in creating truly accessible library resources. By examining the library homepages, this research will not only ascertain the level of ADA compliance, but will also determine the degree of adherence to the philosophical code of librarianship and the desire to provide information to all in a truly inclusive, barrier-free learning environment.

This research was conducted to answer the following questions:

1. How accessible are the library homepages of the topranked US PPIs in terms of Section 508 standards and WCAG guidelines?

2. What accessibility errors that do not meet ADA compliance are most prevalent?

3. Is there a correlation between ranking and number of accessibility issues?

4. Are PPI library homepages more accessible now than they were pre-COVID-19?

\section{Literature review}

There has been an abundance of studies conducted, pertinent to the various ADA regulations and standards as applied to both public and academic libraries, but there is little research 
focusing solely on library homepages of PPI in the USA and less on how COVID-19 has affected Section 508 compliance for websites. Although the available literature is not specific to private PPIs, many studies and published works hold tremendous significance as models for practical research and for the solutions researchers offer on effectively constructing universally accessible websites.

Numerous studies focusing on web accessibly of academic libraries have been published, and despite the sample populations being fairly dissimilar, there is great value in the methodology, research models, and the solutions presented in these case studies. Providenti [22] evaluates Kentucky's main university and academic websites for web accessibility using Bobby, a website evaluation tool. In 2000, Kentucky, a state with one of the highest disability rates, was one of the 11 states that recognized the need for state legislation to further uphold the federal laws regarding web accessibility (Introduction, para. 2). Fulton [17] also comprehends the need for more states to take action and implement laws supporting the execution of ADA's web accessibility policies as they pertain to libraries because the federal government does not specifically address website accessibility. ${ }^{1}$ The sub-par level of website accessibility found in Providenti's study attributes non-compliance to lack of time to assess and amend these issues as well as the lack of knowledge and understanding to implement web standards (Conclusion, para.46). Blake [6] concurs and does not attribute indifference or disregard the trend of poor website accessibility but "lack of awareness" although "ignorance is rarely an adequate excuse" (para. 12).

There are two case studies that are akin to the analysis of PPI library homepages based on what method the samples were chosen. Both Schmetzke [25] and Lilly and Van Fleet [21] feature population samples from lists of the most elite institutions of their kind. Schmetzke drew from the U.S. News and World Report's list of the highest ranked library schools in the nation, and Lilly and Van Fleet analyzed the top institutions ranked in Yahoo!'s list of the "100 Most Wired Colleges." The sample of PPIs on which this research will focus comes from Money.com's individualized list of the best value private colleges and University 2019.

The methodology of the population samples of both the Schmetzke [25] and the Lilly and Van Fleet [21] research is not the only significant aspect of each respective study. One may assume that due to the basic tenets of librarianship, academic institutions providing specialized degrees in library science would strive to create and maintain equitable access to all web-based information. Yet, according to Schmetzke [25], "Many libraries have not taken the proper action to ensure their web pages are freely accessible to people with

\footnotetext{
1 As of February 12, 2010, only 17 states adopted specific legislation related to library website accessibility [17, pp. 41-43].
}

print disabilities" as he refers to the universities' accessibility records as "dismal" (p. 46). This unfortunate conclusion does not only apply to Schmetzke's work but is also observed by Lilly and Van Fleet [21], Anaya et al. [3], Green and Huprich [19], and Floyd and Santiago [16].

Byerly and Chambers [10] tested the University of Colorado at Colorado Springs Kraemer Family Library website to ensure that the disability community could successfully utilize the website's features. Their approach differs from the aforementioned researchers because it is based on a usability testing model employing human participants who engaged in surveys, interview, and formal testing. Byerly and Chambers chose this model as it is "a means of improving functionality of information gateways because the testing involves students and/or faculty and staff who use the site regularly to conduct library research" (p. 303). Similarly, Dols et al. [13, 14] created a usability accessibility study of different library websites (academic and public) using human participants. Dols et al. explain that usability testing, a widely accepted technique, "is a useful tool for obtaining quick feedback on a product's design," but "it is important to note that the goal of usability testing in capturing users' reactions is merely to improve a product, and not to advance any scientific (or generalizable) discovery of an underlying phenomena in user population" (252).

Although this literature review is not covering studies regarding ADA compliance for public library websites, there is one study worth noting. There is a significant amount of research dedicated to public library websites. Bielefield et al.'s [5] study is beneficial because of the research methodology and similar data collection techniques it presents. The WAVE evaluation tool is utilized similarly as in this study to achieve comparable information.

Most website compliancy studies are dedicated to providing a substantial background and the practical implication of the Americans with Disabilities Act (ADA) website accessibility laws, statutes, and guidelines. The previously mentioned studies include synopses of the legal aspects of web accessibility. However, Providenti and Zai [23] present a comprehensive guide "to clarify the standards, guidelines, and laws which affect web accessibility for academic library web sites in the USA as well as an explanation of the mechanism by which accessibility is enforced" (p. 494). Additionally, WebAIM [28], an organization committed "to empower organizations to make their web content accessible to people with disabilities" presents numerous articles and resources dedicated to educating the public and professionals on the current laws and various legalities surrounding those laws ("Introduction to Web Accessibility"). One of the useful features of the WebAIM website is that it conveniently provides direct links to beneficial sources such as the World Wide Web Consortium (W3C) and Section 508.gov, a federally created website dedicated to the Section 508 amendment to the Rehabilitation Act of 1973. 
Testing and maintaining compliancy with the law is imperative to guarantee proper web accessibility. The American Library Association (ALA) [1] offers two exceptionally useful sources to ensure a website is and remains consistent with the law: "Internet and Web-based Content Accessibility Checklist" and "Internet and Web-based Content Accessibility Evaluation." Both of these guides originate from the Association for Specialized and Cooperative Library Agencies (ASCLA), a division of the ALA, and are designed to help all libraries comply with the most current web accessibility standards. Riley-Huff [24] and Carter [11] build on these checklists and contribute entire articles as website accessibility guides. Not only does Riley-Huff outline how to achieve compliance in a variety of areas including general page design and features, but she also offers a list of useful tools, tests, and services to aid in creating an accessible webpage. Carter goes beyond the technicalities of making content accessible and stresses the importance of having a staff well-trained in diverse learning styles and ADA to "better enable students to conduct research independently" (13).

Because of the recentness of the COVID-19 pandemic, the available literature of its effect on ADA compliance is quite possibly nonexistent. Askew et al. [4] share experiences from their individual libraries during quarantine. The librarians from Augusta University, Georgia Institute of Technology, and Valdosta State University predominantly address online programming challenges and do not consider any compliancy needs. Burns [9] discusses the importance of the preparedness and the hurdles accessing online teaching resources for K-12 librarians during quarantine, while Kim et al. [20] focus on "transforming existing communities of practice within public libraries into online knowledge-building communities" during library closures during the pandemic (p. 619). Although these studies are pertinent to COVID-19 and how libraries and librarians are developing programs and gathering resources virtually, there is a greater lack of literature specifically regarding measures being taken to ensure barrierfree websites in this post-COVID-19 technological world.

This literature review indeed includes research relevant to the accessibility of academic library homepages. Although the research may be germane, there is still an absence of literature dedicated particularly to the nation's top ranked PPIs and the accessibility of their library homepages. The creation and evaluation of ADA compliant web sources, solutions for establishing universally accessible websites, and methodologies used to assess library websites will aid in researching web accessibility of the top PPI library websites.

\section{Research design and methods}

The studied list of private colleges and universities was obtained by using the money.com "Build Your Own Rankings" tool [7], a qualified and credible group of persons were tasked with ranking post-secondary institutions based on quality of education, affordability of the institution, and graduation and earning outcomes. ${ }^{2}$

After attempting to identify the library homepages for all 100 PPIs, it was discovered that three of the PPIs analyzed (Pomona College, Claremont Mckenna College, and Harvey Mudd College) are members of the Claremont Colleges and share the same library. Because of this redundancy, the data for the Claremont Colleges library website was only computed once. Hence, 98 out of the 100 PPI library websites were analyzed for this research.

Using longitude research and analytical comparison methods, the main part of the research examined website accessibility analyses from October 2020. Data from a secondary date, December 2019, is used to determine the level of accessibility pre-COVID-19. Because of the COVID-19 pandemic, many of the PPIs in this study have limited physical access to their library facilities. Institutions are now relying more on online research, virtual reference services, and use of their websites to assist their respective communities.

The data collected was limited to the homepages of libraries. Providenti and Zai [23] suggest that "as the libraries' virtual front door, the home page for a library would most likely be among the sites' most carefully maintained pages, demonstrating the institution's best effort, or, at least, most recent design" (p. 483). Not limiting analysis to the library homepage would produce "undesirable" results as "some catalog and periodical index pages would have been included," according to Schmetzke [25, p. 41]. The results of these specific pages would skew the data collected for the other website components and were therefore not included.

\subsection{Evaluation tool and procedures}

WAVE, a free web accessibility evaluation tool developed and administered by Web Accessibility In Mind, was utilized to assess the accessibility of PPI library homepages for this research. Detected errors indicate that there is direct violation of the Section 508 standards and WCAG guidelines as interpreted by WAVE. The detected alerts are employed to make the user aware of a possible accessibility deficiency. For example, WAVE utilizes a "noscript" icon to indicate that a $<$ noscript $>$ element is present. WAVE explains that if JavaScript is disabled, <noscript $>$ is presented to the user ("Alerts noscript element," n.d.).

It should be noted that the WAVE interface has changed between December 2019 and October 2020. Although the

\footnotetext{
${ }^{2}$ Money.com has employed private educational consultants as well as individuals now working at the Institute of Educational Sciences, the National Center of Education Evaluation and Regional Assistance at the Institute of Educational Sciences, and the American Association of State Colleges and Universities for their expertise in creating their ranking system.
} 
functionalities are almost identical, the fonts and icons have been slightly modified.

The result view from the December 2019 data collection is comparable to the October 2020 view of the displayed analysis.

The sidebars in both the 2019 and 2020 versions of WAVE contain the same evaluation parameters: summary, details, documentation/reference (2019 and 2020, respectively), outline/structure (2019 and 2020, respectively), and contrast. Each version also allows the user the option to view the results with or without styles.

\subsection{Description of data collection}

Library homepages were checked for accessibility errors in October 2020 to determine the level of ADA, Section 508, and WCAG compliance. Types of errors and their frequency were recorded to determine the most common compliance issues among the top-ranked PPIs. Further, each PPI was evaluated to ascertain its level of compliance by recording the number of violations of each respective institution.

Each library homepage was tested for WebAIM's versions of Section 508 standards and WCAG guidelines. WebAIM's Section 508 checklist for HTML features 16 checkpoints that function in pass/fail analyses. WebAIM's WCAG interpretation consists of 61 checkpoints that are arranged by the four encompassing principles of WCAG:

- Perceivable: Web content is made available to the senses—sight, hearing, and/or touch;

- Operable: Interface forms, controls, and navigation are operable;

- Understandable: Content and interface are understandable;

- Robust: Content can be used reliably by a wide variety of user agents, including assistive technologies ("WCAG 2.0 Checklist,” 2013).

The PPIs were also evaluated with WAVE in December 2019. The recorded number of library webpage errors will be used in a comparative analysis of pre- and post-COVID-19 accessibility. The values identified in December 2019 only include the number of errors found on each PPI library homepage. However, the data does not include the specific errors recorded. Although there is limited data collected from this date, there is sufficiently meaningful evidence to conduct a general pre- and post-COVID-19 analysis.

\subsection{Analytical methods}

Upon evaluating each library homepage with WAVE, the data associated with the number of errors and alerts was organized in a number of tables and graphs to visually demonstrate volume and frequency in relation to Section 508 standards, the errors themselves, and the accessibility offenses by the topranked PPI. Moreover, a visual analysis is used to illustrate Section 508 compliance in a post-COVID-19 academia. The statistical information was calculated using Microsoft Excel's programmed formulas. The charts, tables, and appendices were also created using Excel. This research will round all decimal places to the hundredths.

The presence of previous statistical data regarding topranked PPI libraries and web accessibility is lacking and therefore allows the researcher to analyze the findings directly and effectively. This research will present the collected data in a comparative method to determine the level of awareness each PPI school has in respect to web accessibility and its library. The data will conclude in what areas the libraries are the most frequently and if elevated use of virtual research post-COVID-19 has pushed PPI libraries to upgrade website accessibility where needed.

\section{Results and discussion}

Upon evaluation, the data collected revealed that the majority of the top-ranked PPI library homepages were characterized by an alarming number of errors. An unexpectedly large portion of the institutions evaluated have accessibility issues in direct conflict with Section 508 of the Rehabilitation Act and WCAG.

Out of the 98 library homepages analyzed, there were only nine libraries that were void of any accessibility errors, Section 508 or otherwise Further, only 15 libraries adhere to the laws established in Section 508 of the Rehabilitation Act. "Appendix" shows the top-ranked US PPIs and if their library homepages are compliant with the ADA, Section 508, standards and WCA guidelines. Only $24.49 \%$ of the library homepages surveyed are Section 508 compliant (Fig. 1), and a meager $9.18 \%$ are completely error-free (Fig. 2; Table 1).

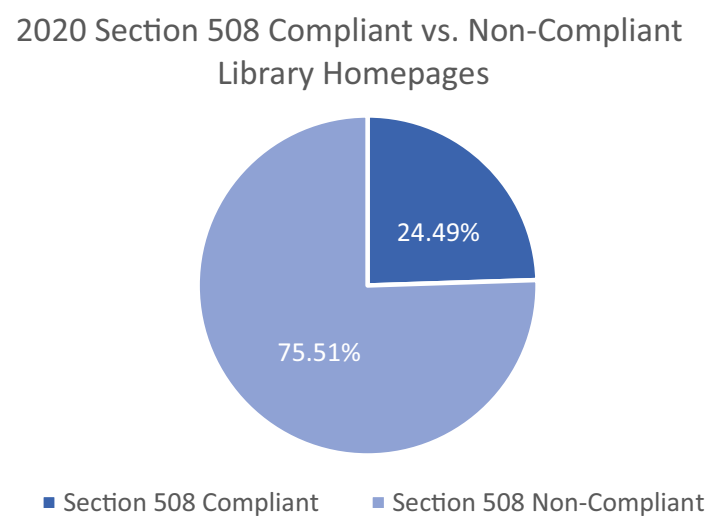

Fig. 1 Percentage of library homepages that have no Section 508 errors vs. those that do have Section 508 errors 
2020 Library Homepages with Errors vs. Library Homepages without Errors

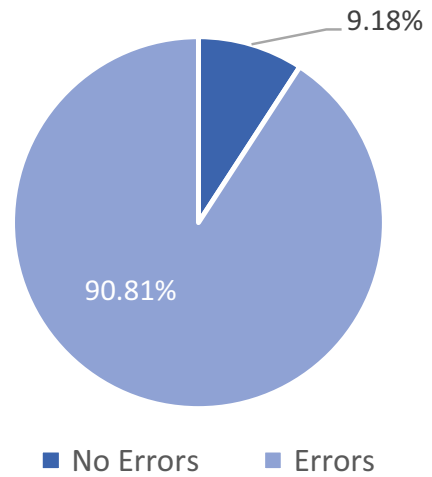

Fig. 2 Percentage of library homepages that have no errors vs. those that do have errors

\subsection{Contrast errors most frequently observed}

The bulk of the detected errors in this study are visually based offenses and directly impact those users with visual impairments such as blindness, low vision, and colorblindness. The low contrast aesthetics, particularly specific color combinations and text proportions, distort the webpage's content and key features. The preponderance of Section 508 violations inhibits screen readers from effectively communicating accurate and complete information to the user.

Overall, most errors are categorized as contrast errors, specifically those relating to very low contrast. Contrast errors accounted for slightly more than half of the aggregate of all errors at $50.71 \%$ and appeared on 76 out of 98 library homepages (Tables 2, 3). Satisfactory contrast between text and background color is necessary for all users but especially for those with low vision. According to WebAIM [28], "text and images of text have a contrast ratio of at least 4.5:1" and "large text-at least 18 point (typically $24 \mathrm{px}$ ) or 14 point (typically 18.66px) and bold-has a contrast ratio of at least 3:1" ("WebAIM's WCAG 2 checklist"). The simple remedy for this is to increase contrast between the color of the text and the color of the background. Moreover, an enlarged font will create a greater contrast.

\subsection{Section 508 errors are widespread}

The remaining $49.29 \%$ of errors can be attributed to Section 508 errors (49.04\%) and the language missing or invalid error $(0.25 \%)$. The highest percentage of Section 508 errors occurred in Section 508(a) at 16.46\%. Section 508(n) and Section 508(c) are the next most-represented subsections with $15.28 \%$ and $14.95 \%$ of the total errors, respectively. Figure 3 illustrates how the errors were distributed throughout the surveyed webpages (Table 4; Fig. 4).

Section 508(a) standards correspond with the WAVE guideline of creating and implementing "Perceivable" website content. According to this guideline, website features should yield usability for those with visual, aural, and/or kinesthetic impairments. All Section 508(a) errors identified in this study (empty button, linked image missing alternative text, missing alternative text, and spacer image missing alternative text) interfere with the functionality of screen readers. The errors of Section 508(a) inhibit a screen reader to effectively assist the user to fully access a website's content. Without proper explanation of non-text elements, the user will be presented with an incomplete version of a webpage and be unable to obtain pertinent information.
Table 1 Section 508 criteria with specific errors displayed by number and frequency

\begin{tabular}{lllc}
\hline Section & Specific error & $\begin{array}{l}\text { Occurrences of } \\
\text { error }\end{array}$ & $\begin{array}{l}\text { Percentage of } \\
\text { total errors }\end{array}$ \\
\hline 508(a) & Empty button & 100 & 8.35 \\
& Linked image missing alternative text & 78 & 6.52 \\
& Missing alternative text & 16 & 1.34 \\
& Spacer image missing alternative text & 3 & 0.25 \\
$508(\mathrm{c})$ & Empty link & 123 & 10.28 \\
& Broken ARIA menu & 35 & 2.92 \\
& Broken ARIA reference & 21 & 1.75 \\
$508(\mathrm{~g})$, 508(h) & Empty table header & 9 & 0.75 \\
$508(\mathrm{n})$ & Multiple form labels & 43 & 3.59 \\
& Missing form label & 139 & 11.61 \\
& Empty form label & 1 & 0.08 \\
$508(\mathrm{o})$ & Empty heading & 18 & 1.5 \\
& Broken skip link & 1 & 0.08 \\
& Other errors & & \\
& Language missing or invalid & 3 & 0.25 \\
& Contrast errors-very low contrast & 607 & 50.71 \\
\hline
\end{tabular}


Table 2 Library homepages with Section 508 errors by volume and frequency

\begin{tabular}{|c|c|c|c|}
\hline Section & Specific error & $\begin{array}{l}\text { Number of library homepages with } \\
\text { specific error }\end{array}$ & $\begin{array}{l}\text { Percentage of library } \\
\text { homepages with specific } \\
\text { error }\end{array}$ \\
\hline \multirow[t]{4}{*}{$508(a)$} & Empty button & 20 & 20.41 \\
\hline & Linked image missing alternative text & 18 & 18.37 \\
\hline & Missing alternative text & 9 & 9.18 \\
\hline & Spacer image missing alternative text & 2 & 2.04 \\
\hline \multirow[t]{3}{*}{$508(\mathrm{c})$} & Empty link & 20 & 20.41 \\
\hline & Broken ARIA menu & 13 & 13.27 \\
\hline & Broken ARIA reference & 5 & 5.1 \\
\hline $508(\mathrm{~g}), 508(\mathrm{~h})$ & Empty table header & 3 & 3.06 \\
\hline \multirow[t]{3}{*}{$508(n)$} & Multiple form labels & 8 & 8.16 \\
\hline & Missing form label & 39 & 39.8 \\
\hline & Empty form label & 1 & 1.02 \\
\hline \multirow[t]{5}{*}{$508(0)$} & Empty heading & 10 & 10.2 \\
\hline & Broken skip link & 1 & 1.02 \\
\hline & Other errors & & \\
\hline & Language missing or invalid & 3 & 3.06 \\
\hline & Contrast errors-very low contrast & 76 & 77.56 \\
\hline
\end{tabular}

The empty button was recorded a dispiriting 100 times by WAVE. The empty button error indicates that there is no description or content present that denotes the purpose of that particular button. Furthermore, screen readers receive information devoid of any substance and are rendered useless for those with visual impairments.

Screen reader usability is also impacted by Section 508(n) errors found in this study which accounted for 183 of the total 1197 website accessibility errors. The occurrence of multiple form labels and missing form labels implies that said labels lack clarity and satisfactory descriptions. This is in direct violation of WCAG's guideline of "Operability." Supplying a more accurate description or straightforward label would appropriately amend this accessibility issue and allow screen readers to function without encumbrance.

\subsection{Number of errors unrelated to library ranking}

This study found that there is no significant connection between the ranking of a PPI and the accessibility of its library homepage. In respect to institution ranking and number of WAVE determined accessibility errors, the correlation coefficient is (r), having a weak linear trend. There is an approximate $(25 \%)$ relationship between the rankings and number of errors. Because the correlation coefficient is close to zero, it is determined that statistically there is no significant linear relationship between the two values (Fig. 5).

The data demonstrates that the errors are not exclusive to schools that are valued and epitomized less than others.
Rankings, prestige, affordability and graduation success rates have very little to do with how well an institution complies with laws and regulations established to protect and aid those with disabilities.

\subsection{Insignificant decrease in accessibility errors post-COVID-19}

Academic libraries have been forced to adapt to a new model of disseminating information and offering basic services amidst the global pandemic. The majority of libraries in this study have either offered modified services or sadly, have closed temporarily. A considerable amount of PPIs have restricted the limited library resources solely to those members of their institution's community (faculty, staff, and students).

Based on the data collected with WAVE, there were 749 Section 508 errors recorded in December 2019 (preCOVID-19), and 588 Section 508 errors recorded in October 2020 (post-COVID-19). By utilizing the percentage change formula, the data indicates a $21.5 \%$ decrease in Section 508 errors from pre- to post-COVID-19. With the preponderance of virtual learning and the growing reliance on web-based research, it is disturbing that PPI are not striving to create and maintain flawless websites accessible to all (Fig. 6).

Only 38 of the PPIs showed fewer Section 508 errors in October 2020 than they showed in December 2019, while 28 had an increase in errors, and 32 library websites maintained the status quo and exhibited no change in errors at 
Table 3 Percentage of errors found on PPI library homepages per October 2020 analysis

\begin{tabular}{ll}
\hline Specific error & $\begin{array}{l}\text { Percentage of } \\
\text { total errors }\end{array}$ \\
\hline Very low contrast non-508 & 50.71 \\
Missing form label 508(n) & 11.61 \\
Empty link 508(c) & 10.28 \\
Empty button 508(a) & 8.35 \\
Linked image missing alternative text 508(a) & 6.52 \\
Multiple form labels 508(n) & 3.59 \\
Broken ARIA menu 508(c) & 2.92 \\
Broken ARIA reference 508(c) & 1.75 \\
Empty heading 508(o) & 1.5 \\
Missing alternative text 508(a) & 1.34 \\
Empty table header 508(g), 508(h) & 0.75 \\
Spacer image missing alternative text 508(a) & 0.25 \\
Language missing or invalid non-508 & 0.25 \\
Broken skip link 508(o) & 0.08 \\
Empty form label 508(n) & 0.08 \\
\hline
\end{tabular}

all. Columbia University (23), Occidental College (98), and Villanova University (74) experienced substantial decreases in their post-COVID-19 WAVE analysis at 91, 56, and 29, respectively. Unfortunately, there were significant increases in post-COVID-19 testing as well. Section 508 errors for Martin Luther College (31) rose to 74. Emory University (58) and Hamilton College (31) are the second and third biggest offenders with error increases of 43 and 20, respectively (Table 5).

Fig. 3 Percentage of errors found on PPI library homepages per October 2020 analysis
Table 4 Occurrences of specific errors on 2020 PPI library homepages

\begin{tabular}{ll}
\hline Specific error & $\begin{array}{l}\text { Occur- } \\
\text { rences of } \\
\text { error }\end{array}$ \\
\hline Contrast errors & 607 \\
Missing form label 508(n) & 139 \\
Empty link 508(c) & 123 \\
Empty button 508(a) & 100 \\
Linked image missing alternative text 508(a) & 78 \\
Multiple form labels 508(n) & 43 \\
Broken ARIA menu 508(c) & 35 \\
Broken ARIA reference 508(c) & 21 \\
Empty heading 508(o) & 18 \\
Missing alternative text 508(a) & 16 \\
Empty table header 508(g), 508(h) & 9 \\
Spacer image missing alternative text 508(a) & 3 \\
Language missing or invalid & 3 \\
Broken skip link 508(o) & 1 \\
Empty form label 508(n) & 1 \\
& 1197 \\
\hline
\end{tabular}

\section{Recommendations}

The creation and maintenance of universally accessible webpages does not have to be a time-consuming, expensive process. However, if an institution is in the financial position to outsource for web maintenance, there are numerous companies that will regularly check webpages for compliance with accessibility standards and regulations. WebAIM offers to certify a website free of charge, but one must pay

\section{Percentage of Total Errors}

- Percentage of Total Errors

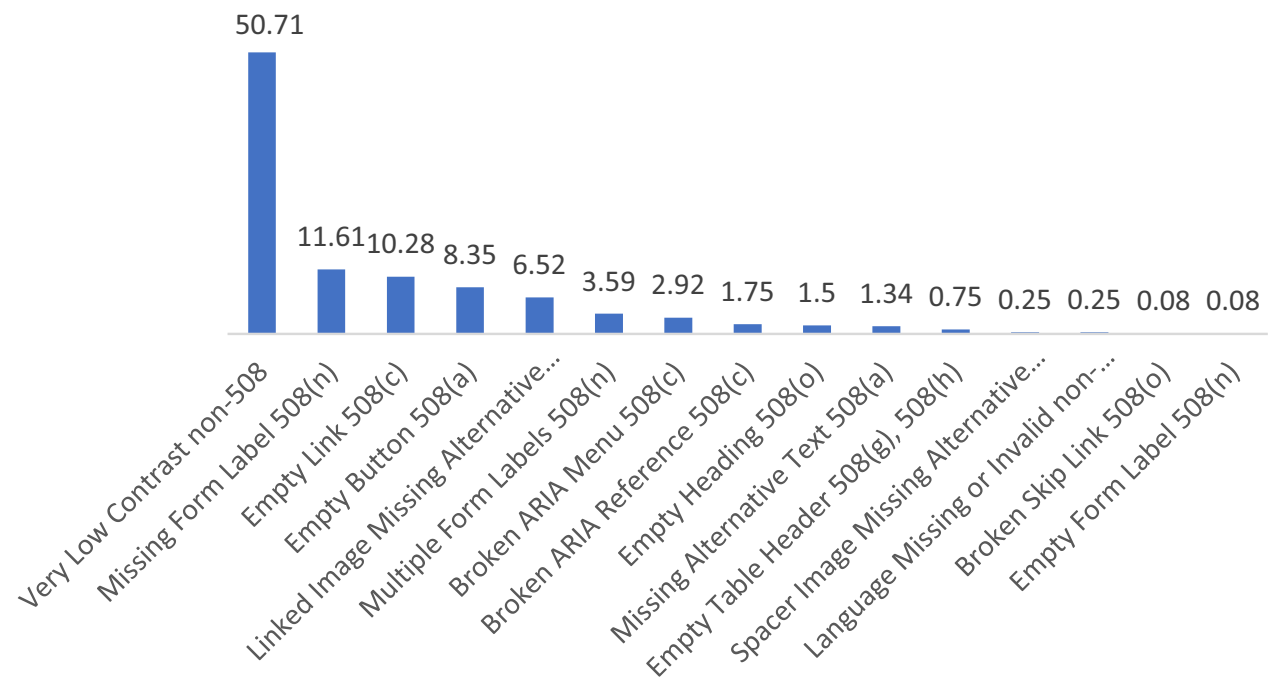


for the initial evaluation. The cost of an evaluation is based on "the size, complexity, and current accessibility of your web site" but is "reasonably priced" [27]. Although hiring a private company to evaluate and correct any accessibility errors on webpages is a satisfactory option, the following methods focus more on collaborative efforts made by the individual libraries and schools to promote awareness and provide a community-based approach to foster accessibility.

\subsection{Establish accountability}

An affordable, simple way to ensure web accessibility issues are addressed is to include very discernible contact information for questions and concerns related to accessibility issues on the library websites. Webpages should clearly state the department or person and title overseeing web accessibility and include various methods of contact.

Having patrons directly inform the library staff of accessibility issues as they arise will not only helps the staff stay abreast of maintaining universal accessibility, but also offers an instrument for patrons to voice-specific needs and concerns that may be overlooked. Further, Anaya et al. [3] recommend appointing a library coordinator to not only field concerns and issues by patrons but also act as a liaison between the library and other pertinent school departments and the school community as a whole (47). Creating detailed contact information for concerned patrons is an effective way to create accountability and also to be made aware of accessibility issues as they arise.

\subsection{Inform patrons}

Including contact information to allow patrons to express accessibility concerns does not only heighten accountability among the library staff, but also fosters a collaborative effort with the patrons. Allowing patrons to conveniently voice their concerns with accessibility issues indicates the PPI's desire to achieve a truly inclusive community. Moreover, it demonstrates that the institutions genuinely hold value in providing the necessary and proper means to everyone for achieving personal, social, and academic development.

Burgstahler et al. [8] share a fine example from the DO-IT homepage as to what should be included in an accessibility statement addressed to the patrons:

The Do-It pages form a living document and are regularly updated. We strive to make them universally accessible. You will notice that we minimize the use of graphics and photos and provide descriptions of them when they are included. Video clips are open captioned, providing access to users who cannot hear the audio. Suggestions for increasing accessibility of these pages are welcome (para. 9).

This statement demonstrates the desire for the institution to comply with accessibility standards and guidelines to effectively disseminate information to those who seek it. It is important to note that the passage is written in very straightforward and clear terms that can be understood by those without any extensive knowledge of web accessibility standards and guidelines.
Fig. 4 Occurrences of specific errors on 2020 PPI library homepages
Occurences of Specific Errors in

2020 PPI Library Homepages

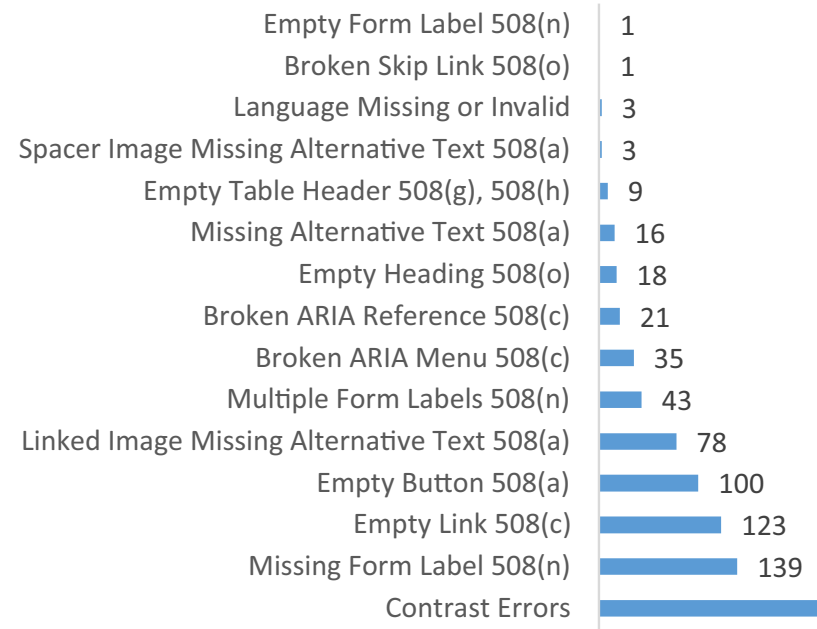




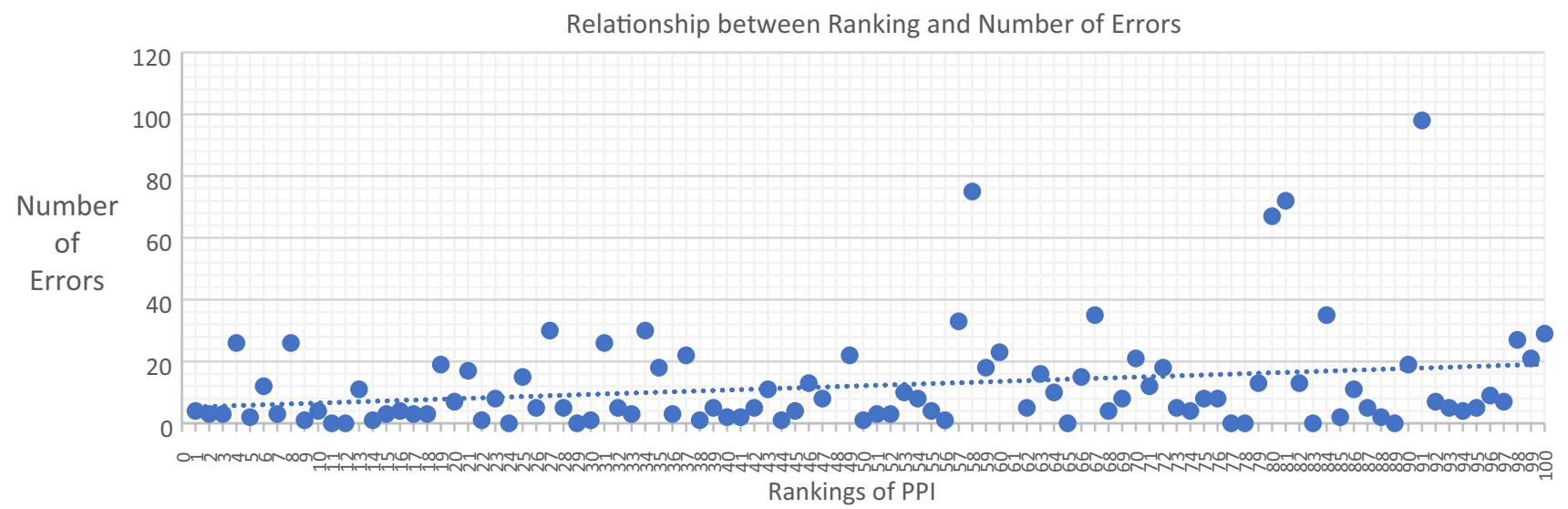

Fig. 5 Based on the information in "Appendix"

\subsection{Foster awareness}

After affording patrons with an efficient means to express their concerns in relation to web accessibility vis-à-vis in the aforementioned sections, one of the concurrent actions is to educate library staff and those involved with constructing and managing the library website. Sharing knowledge and information is a free and effective way to promote accessibility awareness.

Most importantly, the library staff should be reminded of the principles stated in the Library Bill of Rights, particularly those applicable to providing limitless accessibility to all. The obligation to grant access to knowledge should never be compromised not forgotten by anyone in the library profession.

\section{Section 508 Compliant vs. Non-Compliant Library Homepages}

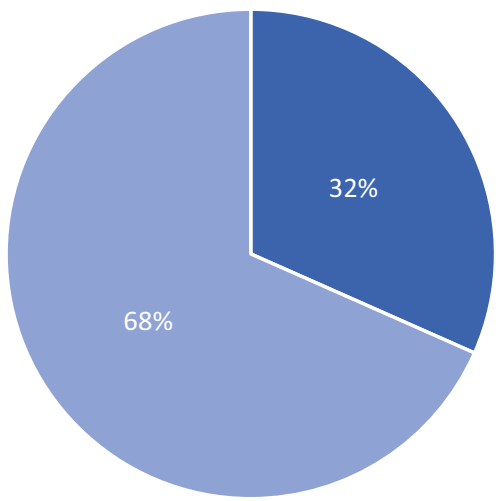

- Section 508 Compliant $\quad$ Section 508 Non-Compliant

Fig. 62019 Section 508 compliant vs. non-compliant library homepages
PPI library staff should be required to read Section 508 and the WCAG guidelines regardless if they are mandated by law to offer universal accessibility. Web accessibility awareness should not end with the library staff but continues to other people and departments involved with web development. An appointed or volunteer library liaison could regularly meet with and discuss pressing accessibility issues that have been discovered by library staff members and/or patrons. Additionally, the library liaison should meet with other groups in the institution's community to propagate awareness and understanding and provide important resources such as web standards and guidelines to familiarize the entire community with web accessibility compliance.

\section{Conclusion}

By examining and analyzing a variety of data sets, it can be determined that the majority of the top-ranked US PPI libraries present widespread accessibility errors, most of which directly affect users with visual impairments. Contrast errors and Section 508(a) errors collectively dominate the areas of concern.

After analyzing the WAVE data collected from December 2019 and October 2020, it can be concluded that most libraries did not consciously remediate accessibility errors to accommodate the uptick in online research and reference due to COVID-19. PPI libraries were certainly cognizant of the shift to virtual learning and research, yet they did not reconcile many of the standing accessibility violations for those patrons living with various impairments.

The results of this study overall are quite disheartening. The data demonstrates the predominant lack of awareness or perhaps even indifference of PPI towards universal web 
Table 5 Top-ranked PPI library homepages with Section 508 errors pre-COVID-19 and post-COVID-19

\begin{tabular}{|c|c|c|c|}
\hline & College name & $\begin{array}{l}\text { Number of errors pre-COVID-19, } \\
\text { December } 2019\end{array}$ & $\begin{array}{l}\text { Number of errors post- } \\
\text { COVID-19, October } \\
2020\end{array}$ \\
\hline 1 & Princeton University & 0 & 2 \\
\hline 2 & Stanford University & 3 & 3 \\
\hline 3 & Massachusetts Institute of Technology & 1 & 1 \\
\hline 4 & California Institute of Technology & 21 & 15 \\
\hline 5 & Rice University & 1 & 1 \\
\hline 6 & University of Pennsylvania & 0 & 0 \\
\hline 7 & Yale University & 4 & 3 \\
\hline 8 & Harvard University & 6 & 0 \\
\hline 9 & Vanderbilt University & 0 & 0 \\
\hline 10 & Washington and Lee University & 5 & 4 \\
\hline 11 & University of Notre Dame & 0 & 0 \\
\hline 12 & Duke University & 0 & 0 \\
\hline 13 & Williams College & 1 & 5 \\
\hline 14 & University of Chicago & 2 & 1 \\
\hline 15 & College of the Holy Cross & 0 & 0 \\
\hline 16 & Swarthmore College & 3 & 2 \\
\hline 17 & Dartmouth College & 0 & 0 \\
\hline 18 & Georgetown University & 3 & 3 \\
\hline 19 & Bates College & 28 & 12 \\
\hline 20 & Union College & 4 & 2 \\
\hline 21 & Barnard College & 12 & 12 \\
\hline 22 & Colgate University & 2 & 1 \\
\hline 23 & Columbia University in the City of New York & 99 & 8 \\
\hline 24 & Brown University & 0 & 0 \\
\hline 25 & Boston College & 0 & 0 \\
\hline 26 & Babson College & 4 & 2 \\
\hline 27 & Amherst College & 3 & 3 \\
\hline 28 & Pomona College & 0 & 5 \\
\hline 29 & Davidson College & 0 & 0 \\
\hline 30 & Haverford College & 6 & 1 \\
\hline 31 & Hamilton College & 4 & 24 \\
\hline 32 & Bowdoin College & 0 & 1 \\
\hline 33 & Saint Johns University & 1 & 2 \\
\hline 34 & Lafayette College & 16 & 11 \\
\hline 35 & Vassar College & 4 & 5 \\
\hline 36 & Bentley University & 1 & 2 \\
\hline 37 & Northwestern University & 8 & 1 \\
\hline 38 & Wellesley College & 0 & 0 \\
\hline 39 & Wake Forest University & 0 & 0 \\
\hline 40 & College of Saint Benedict & 2 & 1 \\
\hline 41 & Cornell University & 1 & 1 \\
\hline 42 & DePauw University & 17 & 0 \\
\hline 43 & Tufts University & 1 & 3 \\
\hline 44 & Brigham Young University-Provo & 3 & 1 \\
\hline 45 & Santa Clara University & 2 & 2 \\
\hline 46 & University of Richmond & 5 & 4 \\
\hline 47 & Johns Hopkins University & 1 & 1 \\
\hline 48 & Claremont McKenna College & & - \\
\hline
\end{tabular}


Table 5 (continued)

College name
Number of errors pre-COVID-19, December 2019
Number of errors postCOVID-19, October 2020
49

50

51

52

53

54

55

56

57

58

59

60

61

62

63

64

65

66

67

68

69

70

71

72
Simmons College

Wesleyan University

University of Southern California

University of Portland

Lehigh University

Cooper Union for the Advancement of Science and Art

Northeastern University

Franklin and Marshall College

Bucknell University

Emory University

Washington University in St. Louis

Colby College

Harvey Mudd College

St. Lawrence University

College of the Ozarks

Molloy College

College of Mount Saint Vincent

Siena College

Trinity University

Gustavus Adolphus College

Gettysburg College

Wabash College

Wheaton College - Illinois

St. Olaf College

Stevens Institute of Technology

Villanova University

Carnegie Mellon University

Middlebury College

Syracuse University

The College of Saint Scholastica

Worcester Polytechnic Institute

Fairfield University

Bethel University

Saint Mary's College

McDaniel College

Art Center College of Design

Marquette University

St. Catherine University

Assumption College

Providence College

Lake Forest College

Holy Family University

Martin Luther College

Touro College

Case Western Reserve University

Brandeis University

MCPHS University

University of Rochester

15

1

0

2

5

1

4

0

5

46

17

17

$-$

2

4

9

0

13

24

5

0

16

0

15

3

3

7

4

0

0

10

23

53

1

0

10

1

8

3

1

0

0

74

2

3

4

2

4 
Table 5 (continued)

\begin{tabular}{|c|c|c|c|}
\hline & College name & $\begin{array}{l}\text { Number of errors pre-COVID-19, } \\
\text { December } 2019\end{array}$ & $\begin{array}{l}\text { Number of errors post- } \\
\text { COVID-19, October } \\
2020\end{array}$ \\
\hline 97 & Boston University & 2 & 6 \\
\hline 98 & Occidental College & 56 & 0 \\
\hline 99 & Merrimack College & 24 & 6 \\
\hline 100 & St. Thomas Aquinas College & 10 & 14 \\
\hline
\end{tabular}

accessibility. As well-funded, socially conscious institutions, the schools should have a profound sense of moral and of course legal obligation to their respective communities. There is a variety of ways to foster this awareness that are budget-friendly and undoubtedly beneficial for the institution as a whole.

It is hopeful that legislation will continue to be created and amended to protect the rights of individuals with disabilities. Until then, it is the legal and moral responsibility of United States PPI libraries to adhere to the tenets of the Library Bill of Rights and actively champion to provide ADA compliant websites. Creating meaningful relationships with students, staff, and faculty at each respective institution will open dialogue and garner awareness for accessibility issues thus yielding truly inclusive communities.

\section{Appendix: List of libraries with compliance indicators}

\begin{tabular}{|c|c|c|c|c|}
\hline Ranking & College name & $\begin{array}{l}\text { Number of } \\
\text { Section } 508 \\
\text { errors }\end{array}$ & $\begin{array}{l}\text { Number of } \\
\text { total errors }\end{array}$ & $\begin{array}{l}\text { ADA } \\
\text { compli- } \\
\text { ant }\end{array}$ \\
\hline 1 & $\begin{array}{l}\text { Princeton } \\
\text { University }\end{array}$ & 0 & 4 & $\mathrm{~N}$ \\
\hline 2 & $\begin{array}{l}\text { Stanford } \\
\text { University }\end{array}$ & 3 & 3 & $\mathrm{~N}$ \\
\hline 3 & $\begin{array}{l}\text { Massachusetts } \\
\text { Institute of } \\
\text { Technology }\end{array}$ & 1 & 3 & $\mathrm{~N}$ \\
\hline 4 & $\begin{array}{l}\text { California } \\
\text { Institute of } \\
\text { Technology }\end{array}$ & 21 & 26 & $\mathrm{~N}$ \\
\hline 5 & $\begin{array}{l}\text { Rice Univer- } \\
\text { sity }\end{array}$ & 1 & 2 & $\mathrm{~N}$ \\
\hline 6 & $\begin{array}{l}\text { University of } \\
\text { Pennsylva- } \\
\text { nia }\end{array}$ & 0 & 12 & $\mathrm{~N}$ \\
\hline 7 & $\begin{array}{l}\text { Yale Univer- } \\
\text { sity }\end{array}$ & 4 & 3 & $\mathrm{~N}$ \\
\hline 8 & $\begin{array}{l}\text { Harvard Uni- } \\
\text { versity }\end{array}$ & 6 & 26 & $\mathrm{~N}$ \\
\hline
\end{tabular}

\begin{tabular}{|c|c|c|c|c|}
\hline Ranking & College name & $\begin{array}{l}\text { Number of } \\
\text { Section } 508 \\
\text { errors }\end{array}$ & $\begin{array}{l}\text { Number of } \\
\text { total errors }\end{array}$ & $\begin{array}{l}\text { ADA } \\
\text { compli- } \\
\text { ant }\end{array}$ \\
\hline 9 & $\begin{array}{l}\text { Vanderbilt } \\
\text { University }\end{array}$ & 0 & 1 & $\mathrm{~N}$ \\
\hline 10 & $\begin{array}{l}\text { Washington } \\
\text { and Lee } \\
\text { University }\end{array}$ & 5 & 4 & $\mathrm{~N}$ \\
\hline 11 & $\begin{array}{l}\text { University of } \\
\text { Notre Dame }\end{array}$ & 0 & 0 & $\mathrm{Y}$ \\
\hline 12 & $\begin{array}{l}\text { Duke Univer- } \\
\text { sity }\end{array}$ & 0 & 0 & $\mathrm{Y}$ \\
\hline 13 & $\begin{array}{l}\text { Williams Col- } \\
\text { lege }\end{array}$ & 1 & 11 & $\mathrm{~N}$ \\
\hline 14 & $\begin{array}{l}\text { University of } \\
\text { Chicago }\end{array}$ & 2 & 1 & $\mathrm{~N}$ \\
\hline 15 & $\begin{array}{c}\text { College of the } \\
\text { Holy Cross }\end{array}$ & 0 & 3 & $\mathrm{~N}$ \\
\hline 16 & $\begin{array}{l}\text { Swarthmore } \\
\text { College }\end{array}$ & 3 & 4 & $\mathrm{~N}$ \\
\hline 17 & $\begin{array}{l}\text { Dartmouth } \\
\text { College }\end{array}$ & 0 & 3 & $\mathrm{~N}$ \\
\hline 18 & $\begin{array}{r}\text { Georgetown } \\
\text { University }\end{array}$ & 3 & 3 & $\mathrm{~N}$ \\
\hline 19 & Bates College & 28 & 19 & $\mathrm{~N}$ \\
\hline 20 & $\begin{array}{l}\text { Union Col- } \\
\text { lege }\end{array}$ & 4 & 7 & $\mathrm{~N}$ \\
\hline 21 & $\begin{array}{l}\text { Barnard Col- } \\
\text { lege }\end{array}$ & 12 & 17 & $\mathrm{~N}$ \\
\hline 22 & $\begin{array}{l}\text { Colgate Uni- } \\
\text { versity }\end{array}$ & 2 & 1 & $\mathrm{~N}$ \\
\hline 23 & $\begin{array}{l}\text { Columbia } \\
\text { University } \\
\text { in the City } \\
\text { of New } \\
\text { York }\end{array}$ & 99 & 8 & $\mathrm{~N}$ \\
\hline 24 & $\begin{array}{l}\text { Brown Uni- } \\
\text { versity }\end{array}$ & 0 & 0 & $\mathrm{Y}$ \\
\hline 25 & $\begin{array}{l}\text { Boston Col- } \\
\text { lege }\end{array}$ & 0 & 15 & $\mathrm{~N}$ \\
\hline 26 & $\begin{array}{l}\text { Babson Col- } \\
\text { lege }\end{array}$ & 4 & 5 & $\mathrm{~N}$ \\
\hline 27 & $\begin{array}{l}\text { Amherst Col- } \\
\text { lege }\end{array}$ & 3 & 30 & $\mathrm{~N}$ \\
\hline 28 & $\begin{array}{l}\text { Pomona Col- } \\
\text { lege* }\end{array}$ & 0 & 5 & $\mathrm{~N}$ \\
\hline
\end{tabular}




\begin{tabular}{|c|c|c|c|c|c|c|c|c|c|}
\hline Ranking & College name & $\begin{array}{l}\text { Number of } \\
\text { Section } 508 \\
\text { errors }\end{array}$ & $\begin{array}{l}\text { Number of } \\
\text { total errors }\end{array}$ & $\begin{array}{l}\text { ADA } \\
\text { compli- } \\
\text { ant }\end{array}$ & Ranking & College name & $\begin{array}{l}\text { Number of } \\
\text { Section } 508 \\
\text { errors }\end{array}$ & $\begin{array}{l}\text { Number of } \\
\text { total errors }\end{array}$ & $\begin{array}{l}\text { ADA } \\
\text { compli- } \\
\text { ant }\end{array}$ \\
\hline 29 & $\begin{array}{r}\text { Davidson } \\
\text { College }\end{array}$ & 0 & 0 & Y & 53 & $\begin{array}{l}\text { Lehigh Uni- } \\
\text { versity }\end{array}$ & 0 & 10 & $\mathrm{~N}$ \\
\hline 30 & $\begin{array}{c}\text { Haverford } \\
\text { College }\end{array}$ & 6 & 1 & $\mathrm{~N}$ & \multirow[t]{3}{*}{54} & $\begin{array}{l}\text { Cooper Union } \\
\text { for the }\end{array}$ & \multirow[t]{3}{*}{5} & \multirow[t]{3}{*}{8} & \multirow[t]{3}{*}{$\mathrm{N}$} \\
\hline 31 & $\begin{array}{r}\text { Hamilton } \\
\text { College }\end{array}$ & 4 & 26 & $\mathrm{~N}$ & & $\begin{array}{l}\text { Advance- } \\
\text { ment of }\end{array}$ & & & \\
\hline 32 & $\begin{array}{l}\text { Bowdoin Col- } \\
\text { lege }\end{array}$ & 0 & 5 & $\mathrm{~N}$ & & $\begin{array}{l}\text { Science and } \\
\text { Art }\end{array}$ & & & \\
\hline 33 & $\begin{array}{l}\text { Saint Johns } \\
\text { University }\end{array}$ & 1 & 3 & $\mathrm{~N}$ & 55 & $\begin{array}{l}\text { Northeastern } \\
\text { University }\end{array}$ & 5 & 4 & $\mathrm{~N}$ \\
\hline 34 & $\begin{array}{l}\text { Lafayette Col- } \\
\text { lege }\end{array}$ & 16 & 30 & $\mathrm{~N}$ & 56 & $\begin{array}{l}\text { Franklin and } \\
\text { Marshall } \\
\text { College }\end{array}$ & 0 & 1 & $\mathrm{~N}$ \\
\hline 35 & $\begin{array}{l}\text { Vassar Col- } \\
\text { lege }\end{array}$ & 4 & 18 & $\mathrm{~N}$ & 57 & $\begin{array}{l}\text { Bucknell } \\
\text { University }\end{array}$ & 4 & 33 & $\mathrm{~N}$ \\
\hline 36 & $\begin{array}{l}\text { Bentley Uni- } \\
\text { versity }\end{array}$ & 1 & 3 & $\mathrm{~N}$ & 58 & $\begin{array}{l}\text { Emory Uni- } \\
\text { versity }\end{array}$ & 3 & 75 & $\mathrm{~N}$ \\
\hline 37 & $\begin{array}{l}\text { Northwestern } \\
\text { University }\end{array}$ & 8 & 22 & $\mathrm{~N}$ & \multirow[t]{2}{*}{59} & $\begin{array}{l}\text { Washington } \\
\text { University }\end{array}$ & \multirow[t]{2}{*}{22} & \multirow[t]{2}{*}{18} & \multirow[t]{2}{*}{$\mathrm{N}$} \\
\hline 38 & $\begin{array}{r}\text { Wellesley } \\
\text { College }\end{array}$ & 0 & 1 & $\mathrm{~N}$ & & in St. Louis & & & \\
\hline 39 & $\begin{array}{c}\text { Wake Forest } \\
\text { University }\end{array}$ & 0 & 5 & $\mathrm{~N}$ & 60 & $\begin{array}{l}\text { Colby Col- } \\
\text { lege }\end{array}$ & \multirow[t]{2}{*}{25} & \multirow[t]{2}{*}{23} & \multirow[t]{2}{*}{$\mathrm{N}$} \\
\hline \multirow[t]{2}{*}{40} & \multirow{2}{*}{$\begin{array}{l}\text { College of } \\
\text { Saint Ben- } \\
\text { edict }\end{array}$} & \multirow[t]{2}{*}{2} & \multirow[t]{2}{*}{2} & \multirow[t]{2}{*}{$\mathrm{N}$} & 61 & $\begin{array}{l}\text { Harvey Mudd } \\
\text { College* }\end{array}$ & & & \\
\hline & & & & & 62 & $\begin{array}{l}\text { St. Lawrence } \\
\text { University }\end{array}$ & 0 & 5 & $\mathrm{~N}$ \\
\hline 41 & $\begin{array}{l}\text { Cornell Uni- } \\
\text { versity }\end{array}$ & 1 & 2 & $\mathrm{~N}$ & 63 & $\begin{array}{l}\text { College of the } \\
\text { Ozarks }\end{array}$ & 0 & 16 & $\mathrm{~N}$ \\
\hline 42 & $\begin{array}{l}\text { DePauw } \\
\text { University }\end{array}$ & 17 & 5 & $\mathrm{~N}$ & 64 & $\begin{array}{l}\text { Molloy Col- } \\
\text { lege }\end{array}$ & 1 & 10 & $\mathrm{~N}$ \\
\hline 43 & $\begin{array}{l}\text { Tufts Univer- } \\
\text { sity }\end{array}$ & 1 & 11 & $\mathrm{~N}$ & \multirow[t]{2}{*}{65} & College of & \multirow[t]{2}{*}{0} & \multirow[t]{2}{*}{0} & $\mathrm{Y}$ \\
\hline 44 & Brigham & 3 & 1 & $\mathrm{~N}$ & & Vincent & & & \\
\hline & $\begin{array}{l}\text { Young } \\
\text { University- }\end{array}$ & & & & 66 & Siena College & 12 & 15 & $\mathrm{~N}$ \\
\hline & Provo & & & & 67 & Trinity Uni- & 23 & 35 & $\mathrm{~N}$ \\
\hline 45 & $\begin{array}{l}\text { Santa Clara } \\
\text { University }\end{array}$ & 2 & 4 & $\mathrm{~N}$ & 68 & Gustavus & 8 & 4 & $\mathrm{~N}$ \\
\hline 46 & $\begin{array}{c}\text { University of } \\
\text { Richmond }\end{array}$ & 5 & 13 & $\mathrm{~N}$ & & $\begin{array}{l}\text { Adolphus } \\
\text { College }\end{array}$ & & & \\
\hline 47 & $\begin{array}{l}\text { Johns } \\
\text { Hopkins }\end{array}$ & 1 & 8 & $\mathrm{~N}$ & 69 & $\begin{array}{l}\text { Gettysburg } \\
\text { College }\end{array}$ & 0 & 8 & $\mathrm{~N}$ \\
\hline 48 & University & & & & 70 & $\begin{array}{l}\text { Wabash Col- } \\
\text { lege }\end{array}$ & 16 & 21 & $\mathrm{~N}$ \\
\hline & $\begin{array}{l}\text { Claremont } \\
\text { McKenna } \\
\text { College* }\end{array}$ & & & & 71 & $\begin{array}{l}\text { Wheaton } \\
\text { College- }\end{array}$ & 0 & 12 & $\mathrm{~N}$ \\
\hline 49 & Simmons & 1 & 22 & $\mathrm{~N}$ & & Illinois & & & \\
\hline & College & & & & 72 & $\begin{array}{l}\text { St. Olaf Col- } \\
\text { lege }\end{array}$ & 42 & 18 & $\mathrm{~N}$ \\
\hline & $\begin{array}{l}\text { Wesleyan } \\
\text { University }\end{array}$ & 0 & 1 & $\mathbf{N}$ & 73 & Stevens & 2 & 5 & $\mathrm{~N}$ \\
\hline 51 & $\begin{array}{l}\text { University of } \\
\text { Southern }\end{array}$ & 0 & 3 & $\mathrm{~N}$ & & $\begin{array}{l}\text { Institute of } \\
\text { Technology }\end{array}$ & & & \\
\hline 52 & California & 0 & 3 & $\mathrm{~N}$ & 74 & $\begin{array}{l}\text { Villanova } \\
\text { University }\end{array}$ & 32 & 4 & $\mathrm{~N}$ \\
\hline
\end{tabular}




\begin{tabular}{|c|c|c|c|c|}
\hline Ranking & College name & $\begin{array}{l}\text { Number of } \\
\text { Section } 508 \\
\text { errors }\end{array}$ & $\begin{array}{l}\text { Number of } \\
\text { total errors }\end{array}$ & $\begin{array}{l}\text { ADA } \\
\text { compli- } \\
\text { ant }\end{array}$ \\
\hline 75 & $\begin{array}{l}\text { Carnegie } \\
\text { Mellon Uni- } \\
\text { versity }\end{array}$ & 8 & 8 & $\mathrm{~N}$ \\
\hline 76 & $\begin{array}{l}\text { Middlebury } \\
\text { College }\end{array}$ & 4 & 8 & $\mathrm{~N}$ \\
\hline 77 & $\begin{array}{l}\text { Syracuse } \\
\text { University }\end{array}$ & 0 & 0 & $\mathrm{Y}$ \\
\hline 78 & $\begin{array}{l}\text { The College } \\
\text { of Saint } \\
\text { Scholastica }\end{array}$ & 0 & 0 & $\mathrm{Y}$ \\
\hline 79 & $\begin{array}{l}\text { Worcester } \\
\text { Polytechnic } \\
\text { Institute }\end{array}$ & 0 & 13 & $\mathrm{~N}$ \\
\hline 80 & $\begin{array}{l}\text { Fairfield } \\
\text { University }\end{array}$ & 25 & 67 & $\mathrm{~N}$ \\
\hline 81 & $\begin{array}{l}\text { Bethel Uni- } \\
\text { versity }\end{array}$ & 77 & 72 & $\mathrm{~N}$ \\
\hline 82 & $\begin{array}{l}\text { Saint Mary's } \\
\text { College }\end{array}$ & 1 & 13 & $\mathrm{~N}$ \\
\hline 83 & $\begin{array}{c}\text { McDaniel } \\
\text { College }\end{array}$ & 1 & 0 & $\mathrm{~N}$ \\
\hline 84 & $\begin{array}{l}\text { Art Center } \\
\text { College of } \\
\text { Design }\end{array}$ & 10 & 35 & $\mathrm{~N}$ \\
\hline 85 & $\begin{array}{l}\text { Marquette } \\
\text { University }\end{array}$ & 0 & 2 & $\mathrm{~N}$ \\
\hline 86 & $\begin{array}{l}\text { St. Catherine } \\
\text { University }\end{array}$ & 9 & 11 & $\mathrm{~N}$ \\
\hline 87 & $\begin{array}{l}\text { Assumption } \\
\text { College }\end{array}$ & 2 & 5 & $\mathrm{~N}$ \\
\hline 88 & $\begin{array}{l}\text { Providence } \\
\text { College }\end{array}$ & 2 & 2 & $\mathrm{~N}$ \\
\hline 89 & $\begin{array}{l}\text { Lake Forest } \\
\text { College }\end{array}$ & 0 & 0 & $\mathrm{Y}$ \\
\hline 90 & $\begin{array}{c}\text { Holy Family } \\
\text { University }\end{array}$ & 21 & 19 & $\mathrm{~N}$ \\
\hline 91 & $\begin{array}{l}\text { Martin Luther } \\
\text { College }\end{array}$ & 0 & 98 & $\mathrm{~N}$ \\
\hline 92 & $\begin{array}{l}\text { Touro Col- } \\
\text { lege }\end{array}$ & 0 & 7 & $\mathrm{~N}$ \\
\hline 93 & $\begin{array}{l}\text { Case Western } \\
\text { Reserve } \\
\text { University }\end{array}$ & 7 & 5 & $\mathrm{~N}$ \\
\hline 94 & $\begin{array}{l}\text { Brandeis } \\
\text { University }\end{array}$ & 3 & 4 & $\mathrm{~N}$ \\
\hline 95 & $\begin{array}{l}\text { MCPHS } \\
\text { University }\end{array}$ & 3 & 5 & $\mathrm{~N}$ \\
\hline 96 & $\begin{array}{l}\text { University of } \\
\text { Rochester }\end{array}$ & 9 & 9 & $\mathrm{~N}$ \\
\hline 97 & $\begin{array}{l}\text { Boston Uni- } \\
\text { versity }\end{array}$ & 2 & 7 & $\mathrm{~N}$ \\
\hline 98 & $\begin{array}{l}\text { Occidental } \\
\text { College }\end{array}$ & 56 & 27 & $\mathrm{~N}$ \\
\hline 99 & $\begin{array}{l}\text { Merrimack } \\
\text { College }\end{array}$ & 24 & 21 & $\mathrm{~N}$ \\
\hline
\end{tabular}

\begin{tabular}{lllll}
\hline Ranking & College name & $\begin{array}{l}\text { Number of } \\
\text { Section 508 } \\
\text { errors }\end{array}$ & $\begin{array}{l}\text { Number of } \\
\text { total errors }\end{array}$ & $\begin{array}{l}\text { ADA } \\
\text { compli- } \\
\text { ant }\end{array}$ \\
\hline 100 & $\begin{array}{l}\text { St. Thomas } \\
\text { Aquinas } \\
\text { College }\end{array}$ & 10 & 29 & $\mathrm{~N}$ \\
& & & \\
\hline
\end{tabular}

Author's contributions YQL supervised and directed the research along with Arlene Bielefield; VW performed the material preparation, data collection and analysis and wrote the paper with discussions and contributions from all the authors; $\mathrm{AB}$ initialized the research idea and edited the paper.

Funding The CSU/AAUP fund (2018-19).

Availability of data and materials Upon request.

\section{Declarations}

Conflicts of interest Not applicable.

\section{References}

1. American Library Association: Internet and web-based content accessibility checklist. http://www.ala.org/ascla/asclaprotools/ thinkaccessible/internetwebguidelines (2015)

2. Americans with Disabilities Act of 1990 and revised ADA regulations implementing Title II and Title III. (n.d.). http://www.ada. gov/2010_regs.htm

3. Anaya, T., Cassner, M., Maxey-Harris, C.: Differently able: a review of academic library websites for people with disabilities. Behav. Soc. Sci. Libr. 30(10), 33-51 (2011). https://doi.org/10. 1080/01639269.2011.548722

4. Askew, B., Brown, A., Christy, M., Gomez, A., Gooch, M., Kubicki, J.M., Luster, A., Marseille, D., Paul, S., Smith, L., Tharrington, S., Thornton, A., Tyner, S., Wright, J.D., Slutskaya, S.A.: Georgia libraries respond to COVID-19 pandemic. Ga. Libr. Q. 57(3), 10 (2020)

5. Bielefield, A., Liu, Y.Q., McKay, P.: Are urban public libraries websites accessible to Americans with disabilities? Univ. Access Inf. Soc. 18, 191-206 (2019). https://doi.org/10.1007/ s10209-017-0571-7

6. Blake, S.E.: Universal access, the ADA, and your library webpage. Arkansas Libraries 57(1), 19-24 (2000)

7. Build your own rankings: Find your best value college. (2020). https://money.com/best-colleges/build-your-own-rankings/

8. Burgstahler, S., Comden, D., Fraser, B.M.: Universal Access: Electronic Resources in Libraries. DO-IT (Disabilities, Opportunities, Internetworking, and Technology) at the University of Washington, Seattle, WA. Distributed by the American Library Association (ALA), Washington (1996)

9. Burns, E.: School librarians online: integrated learning beyond the school walls. Inf. Learn. Sci. 121(7/8), 631-644 (2020). https:// doi.org/10.1108/ILS-04-2020-0107

10. Byerly, S., Chambers, M.B.: Usability testing and students with disabilities: achieving universal access on a library web site. In: ACRL Tenth National Conference. Denver, CO. http://www.ala. org/acrl/sites/ala.org.acrl/files/content/conferences/pdf/byerley.pdf (2001) 
11. Carter, C.J.: Providing services for students with disabilities in an academic library. Educ. Libr. 27(2), 13-18 (2004)

12. CASS. (2020). http://cass.caltech.edu

13. Dols, R., Hulscher, L., Newberry, T., Yoon, K.: An exploratory study of library website accessibility for visually impaired users. Libr. Inf. Res. 38, 250-258 (2016). https://doi.org/10.1016/j.lisr. 2016.08.006

14. Dols, R., Hulscher, L., Yoon, K.: Accessibility and diversity in LIS: inclusive information architecture for library websites. Libr. Q. Inf., Commun. Policy 86(2), 213-229 (2016)

15. National Center for Education Statistics: Fast facts: Students with disabilities. https://nces.ed.gov/fastfacts/display.asp?id=60 (n.d.)

16. Floyd, K.S., Santiago, J.: The state of website accessibility in higher education. In: SAIS Proceedings, 20. http://aisel.aisnet. org/sais2007/20 (2007)

17. Fulton, C.: Web accessibility, libraries, and the law. Inf. Technol. Libr. 30(1), 34-43 (2011)

18. Gorman, M.: Our Enduring Values: Librarianship in the 21st Century. American Library Association, Chicago (2000)

19. Green, R.A., Huprich, J.: Web accessibility and accessibility instruction. J. Access Serv. 6(1-2), 116-136 (2009)

20. Kim, S.H., Choi, G.W., Jung, Y.J.: Design principles for transforming making programs into online settings at public libraries. Inf. Learn. Sci. 121(7/8), 619-630 (2020)

21. Lilly, E.B., Van Fleet, C.: Measuring the accessibility of public library home pages. Ref. User Serv. Q. 40(2), 156-165 (2000)
22. Providenti, M.: Library web accessibility at Kentucky's 4-year degree granting colleges and universities. D-Lib Mag. (2004). https://doi.org/10.1045/september2004-providenti

23. Providenti, M., Zai III, R.: Web accessibility at Kentucky's academic libraries. Libr. Hi Tech 25(4), 478-493 (2007). https://doi. org/10.1108/07378830710840446

24. Riley-Huff, D.A.: Web accessibility and universal design: a primer on standards and best practices for libraries. Libr. Technol. Rep. 48(7), 29-35 (2012)

25. Schmetzke, A.: Web accessibility at university libraries and library schools. Libr. Hi Tech 19, 35-49 (2001). https://doi.org/ 10.1108/07378830110384584

26. Web Content Accessibility Guidelines (WCAG). (2020). http:// w3.org/WA/standards-guidelines/wcag/\#for

27. WebAIM services. (n.d.). http://webaim.org/services/

28. WebAIM's WCAG 2 checklist. (2020). https://webaim.org/stand ards/wcag/checklist

29. Website accessibility. (2020). http://richmond.edu/accessibility/

30. What's new in WCAG 2.1. (2020). http://w3.org/WAI/standardsguidelines/wcag/new-in-21/

Publisher's Note Springer Nature remains neutral with regard to jurisdictional claims in published maps and institutional affiliations. 